\title{
Thermostable acidic lipase of Bacillus glycinifermentans-MK840989 isolated from contaminated environment; its optimization, purification and exploring potential applications
}

\begin{abstract}
This study is the first report about isolation, purification and optimization of lipase from Bacillus glycinifermentans. In this study, Bacillus glycinifermentans MK-840989 was isolated from a local petrol pump. The bacterium showed lipolytic zones of $0.19 \mathrm{~cm}$, $0.044 \mathrm{~cm}$, and $0.28 \mathrm{~cm}$ on peptone yeast agar, olive oil hydrolysis agar and chromogenic plate agar, respectively. B. glycinifermentans also produced an extracellular lipase $(55.1 \mu \mathrm{mol} /$ $\mathrm{ml}$ ). This bacterium preferred acidic environment $\left(\mathrm{pH} \mathrm{5)}\right.$ ) for growing optimally at $80^{\circ} \mathrm{C}$ when the medium was supplemented with $1 \%$ olive oil. The olive oil induced its growth up to $9 \mathrm{~h}$. The protein content of the purified lipase was estimated about $75 \mathrm{mg} / \mathrm{ml}$ as compared to its crude form, i.e. $350 \mathrm{mg} / \mathrm{ml}$. The purified lipase was found to be thermostable acidic in nature as its optimum activity was observed at $90^{\circ} \mathrm{C}(0.08 \mathrm{U} / \mathrm{ml})$ and $\mathrm{pH} 5(0.02 \mathrm{U} / \mathrm{ml})$. Other optimization factors included $1 \%$ olive oil $(0.065 \mathrm{U} / \mathrm{ml}), 0.1 \mathrm{mM}$ maltose $(0.023 \mathrm{U} /$ $\mathrm{ml}), 0.1 \mathrm{mM} \mathrm{Ca}(0.025 \mathrm{U} / \mathrm{ml}), 1 \%$ yeast extract $(16.8 \mathrm{U} / \mathrm{ml}), 1 \%$ wheat waste $(0.019 \mathrm{U} / \mathrm{ml})$, $1 \%$ commercial detergent $(0.016 \mathrm{U} / \mathrm{ml})$ and $1 \%$ tween- $20(0.015 \mathrm{U} / \mathrm{ml})$. The purified lipase showed a polypeptide of $26.7 \mathrm{kDa}$ on SDS-PAGE. These features such as thermostability, acidic nature, ability to show activity in wheat waste and tolerance to detergents render the lipase of B.glycinifermentans MK-840989 as an attractive choice for biotechnologists to employ it at industrial level. The purified lipase of B.glycinifermentans MK-840989 can be a potential candidate for detergent and oil-remediation industry. It can help to replace conventional synthetic detergent as it is cost-effective and eco-friendly.
\end{abstract}

Volume 5 Issue 2 - 2020

Saba Shamim,' Shahid Mehboob,' Iftikhar Ali,' Aroosh Shabbir,' Maryam Khan,' Muhammad Ashraf, ${ }^{2}$ Arif Malik'

'Institute of Molecular Biology and Biotechnology (IMBB), The University of Lahore, Pakistan

${ }^{2}$ University of Agriculture, Pakistan

Correspondence: Iftikhar Ali, Institute of Molecular Biology and Biotechnology (IMBB), The University of Lahore, Defence Road Campus, Lahore, Pakistan, Tel +92 3454528975 ,

Email iftikhar_ali_iftikhar@yahoo.com

Received: March 23, 2020 | Published: April 30, 2020

Keywords: bacillus, environmental, enzymes, enzymology, optimization

\section{Introduction}

Microbial enzymes are the biological catalysts that speed up the chemical reactions. They are cost-effective, eco-friendly and highly specific. ${ }^{1}$ The concept of enzyme is as old as human history. ${ }^{2}$ Almost 4000 enzymes exist, among which only 200 are in commercial use. ${ }^{1}$ Of them, $75 \%$ are of microbial origin. ${ }^{3}$ Microorganisms are known to produce many enzymes e.g. amylases, cellulases, proteases, etc.

Lipases (triacyglycerolacylhydrolases, EC 3.1.1.3) are serine hydrolases that convert triacylglycerides into glycerides (diglycerides or monoglycerides) by acting on carboxylic ester bond. ${ }^{4}$ They are extracellular enzymes and are induced by fatty acids, glycerol, oils, hydrolysable esters, etc. ${ }^{5}$ The production of lipase depends on bacterial strain, culture conditions and species. ${ }^{6}$ Different bacterial genera are known to produce lipases e.g. Staphylococcus, Bacillus, ${ }^{7}$ Pseudomonas, ${ }^{6}$ Burkholderia, etc. ${ }^{8-12}$

Pleigoet al. ${ }^{13}$ emphasized on the applications of enzymes at industrial level due to their number of applications in food, leather, dairy, detergents, flavor, pharmaceuticals, cosmetics, biofuels, etc. ${ }^{1}$ Moreover, the optimization of temperature, $\mathrm{pH},{ }^{5}$ agitation, substrate, etc. can enhance the enzymatic activity. ${ }^{14}$ The enzyme purification involves different steps such as ammonium sulfate precipitation, chromatographic techniques including hydrophobic interaction and ion exchange methods. ${ }^{15}$ Since high temperature directly influences the enzyme properties e.g. stability, reaction rate, solubility and lesser substrate viscosity as well as contamination, temperature- stable enzyme is desired. ${ }^{14,16}$ Moreover, the presence of metal ions is reported to improve its lipolytic activity. ${ }^{14,17}$

In this study, an effort is made to explore the lipase producing bacterium from indigenous environment. Here, we report the isolation of lipase producing bacterium, its characterization and growth optimization on different substrates. Furthermore, the lipase purification, optimal production and characterization were also studied.

\section{Materials and methods}

\section{Sample collection, isolation and purification of bacterial isolates}

Different soil samples were collected from motor bike repair shop, oil change service at petrol pump, diesel at railway station, university car parking area and motor bike oil changing local shop. The isolation and purification of bacterial colonies was performed on Luria Bertani (LB) medium supplemented with $1 \%$ olive oil after sterilizing the medium. The cultural, morphological and biochemical characterization of the isolated bacterial colonies obtained were determined. ${ }^{18}$

\section{Screening and selection of lipase producing bacteria}

Following three assays were used to screen the lipase producing bacteria. ${ }^{19}$ 
Olive oil hydrolysis assay: In this method, $1 \%$ olive oil was added to $\mathrm{LB}$ agar plates (tryptone $10 \mathrm{~g}, \mathrm{NaCl} 5 \mathrm{~g}$, yeast extract $5 \mathrm{~g}$, and agar $15 \mathrm{~g}$ ) and zone of lipolysis was observed after incubating the plates at $37^{\circ} \mathrm{C}$ for $24 \mathrm{~h} .^{9}$

Peptone yeast agar assay: The peptone yeast agar medium was prepared by dissolving peptone $10 \mathrm{~g}$, yeast extract $10 \mathrm{~g}$, tween $803 \mathrm{ml}$, olive oil $10 \mathrm{ml}$ and agar $15 \mathrm{~g}$ in one liter of distilled water. The bacterial colonies were streaked on it and incubated for $24 \mathrm{~h}$ at $37^{\circ} \mathrm{C}$. The zone of lipolysis was observed.

Chromogenic plate assay: A minimalmedium containing chromogenic substrate was prepared $(0.01 \%$ phenol red, $4 \%$ tween $80,20 \mathrm{mM} \mathrm{CaCl}_{2}$ and $2 \%$ olive oil and $\left.\mathrm{pH} 7\right)$. All the ingredients were mixed thoroughly in the form of a homogenized paste. Finally, $4 \%$ hot melted agar was added which made its appearance as orange-red color medium, followed by immediate pouring in the Petri plates and solidification at room temperature. By the help of a Pasteur pipette, wells were made in the agar medium and bacterial culture (overnight grown) supernatants added to the wells. The plates were incubated at $37^{\circ} \mathrm{C}$ for $30 \mathrm{~min}$. The change in color from orange-red to yellow was the indication of lipase activity of the bacterial strains. ${ }^{20}$

\section{Selection of efficient lipase producing bacteria}

Based on the results of screening experiments as well as quantification assay, bacterium MK840989 was observed as maximum producer of lipase and thus selected for characterization.

\section{Characterization and optimization of growth conditions of bacterium MK840989}

The cultural, morphological and biochemical characterization of MK840989 was performed. ${ }^{18}$ The molecular characterization and identification on the basis of 16S rRNA gene was obtained from Macrogen ${ }^{\circledR}$ Korea. The optimum temperature, $\mathrm{pH}$ and carbon source for bacterium MK840989 was checked by the method of Liaqat et al. ${ }^{19}$

Optimum temperature: Different temperatures $\left(25,37,50,7090^{\circ} \mathrm{C}\right)$ were selected to check the optimum growth of bacterium MK840989 (Optical density at $580 \mathrm{~nm}$ ) after incubation for $24 \mathrm{~h}$ at respective temperatures.

Optimum pH: The optimum $\mathrm{pH}$ was observed (OD at $580 \mathrm{~nm}$ ) by inoculating the LB broth media of different $\mathrm{pH}(4,5,6,7,8,9)$ followed by incubation at $37^{\circ} \mathrm{C}$ for $24 \mathrm{~h}$.

Optimum carbon source: Different oils (sunflower, canola, olive, mustard, mobile oil) were selected for this experiment. In $5 \mathrm{ml} \mathrm{LB}$ broth, $1 \%$ of each of different oils (sunflower, canola, olive, mustard, mobile oil) was added as a carbon source followed by $1 \%$ inoculum. The test tubes were incubated at $37^{\circ} \mathrm{C}$ for $24 \mathrm{~h}$. Next day, the optical density was observed at $580 \mathrm{~nm}$.

\section{Growth curve analysis}

The effect of oil on the growth of bacterium MK840989 was checked by inoculating the LB growth medium with $1 \%$ olive oil and $1 \%$ culture. The olive oil was not added in the control. The OD was read at $580 \mathrm{~nm}$ after every $1 \mathrm{~h}$ up to $9 \mathrm{~h} .{ }^{19}$

\section{Quantitative analysis of lipase}

Lipase quantity was determined by the method of Bussamaraet al..$^{21}$ The LB medium inoculated with loopful culture and $1 \%$ olive oil was incubated overnight. Culture was harvested at maximum speed for $15 \mathrm{~min}$. In $100 \mu 1$ supernatant, $900 \mu 1$ solution A ( $1 \mathrm{ml}$ solution A: $1 \mathrm{ml}$ isopropanol containing $3 \mathrm{nol}$ palmitate $(\mathrm{pNPP})+9 \mathrm{ml}$ solution $\mathrm{B}$ : $200 \mathrm{ml} 50 \mathrm{mM}$ Tris-Cl pH 8.0, 0.2ml Tween 80, 0.8ml Triton X-100) were added. The mixture was vortexed properly and incubated at $37^{\circ} \mathrm{C}$ for $30 \mathrm{~min}$. The increase in absorbance was read at $410 \mathrm{~nm}$. In control, the olive oil was not used. The lipase activity was calculated. One unit of lipase is the amount of enzyme liberating $1 \mu \mathrm{mol}$ of paranitrophenol per $\mathrm{ml}$ per min under standard assay conditions. ${ }^{22}$

\section{Isolation and purification of lipase}

Lipase purification was done by the method of Liaqat et al. ${ }^{19}$ as described below.

Preparation of phosphate buffer 1M (pH 7.0): Stock solutions of $0.5 \mathrm{M}$ of $\mathrm{Na}_{2} \mathrm{HPO}_{4}$ and $\mathrm{NaH}_{2} \mathrm{PO}_{4}$ were prepared by dissolving $7.098 \mathrm{~g}$ $\mathrm{Na}_{2} \mathrm{HPO}_{4}$ in $80 \mathrm{ml}$ distilled water $(\mathrm{pH} 7.0)$ and $5.99 \mathrm{~g} \mathrm{NaH} \mathrm{PO}_{4}$ in $80 \mathrm{ml}$ distilled water, $(\mathrm{pH} 7.0)$ respectively. The $1 \mathrm{M}$ phosphate buffer (pH 7.0)was prepared by mixing $30 \mathrm{ml}$ of $0.5 \mathrm{M} \mathrm{Na}_{2} \mathrm{HPO}_{4}$ and $80 \mathrm{ml}$ $0.5 \mathrm{M} \mathrm{NaH}_{2} \mathrm{PO}_{4}$. The final volume was made up to $1000 \mathrm{ml}$ by adding distilled water. ${ }^{23}$

Salt precipitation: In supernatant of $1 \mathrm{ml}$ fresh culture, $0.6 \mathrm{~g}$ ammonium sulfate salt was added to obtain $90 \%$ purified enzyme. The salt was thoroughly homogenized by vortex for $10-15 \mathrm{~min}$. followed by cold incubation overnight. It was harvested at maximum speed for 15-30min. The supernatant of jelly-like consistency was shifted to a dialysis membrane. Before shifting, the Bradford assay was performed. ${ }^{24}$

Dialysis: A piece of dialysis membrane $(5 \mathrm{~cm})$ was taken and its one end was folded and closed by a clamp. The jelly-like supernatant obtained in above step was pipetted from other end and closed by folding and clamped. It was suspended in a glass beaker containing $0.1 \mathrm{M}$ phosphate buffer $\mathrm{pH} 7.0$ (prepared above) overnight. The beaker was placed in a refrigerator for overnight. The solution inside the dialysis tubing was shifted to an Eppendorf and centrifuged at following conditions; $1968 \mathrm{x} \mathrm{g}$, for $10 \mathrm{~min}$, and at $4^{\circ} \mathrm{C}$. After harvesting, the supernatant was shifted to a new Eppendorf, and the Bradford assay performed. The sample at this stage was ready for column chromatography.

Colum chromatography: The column was prepared by placing a piece of cotton inside it followed by filling it with Sephadex G-100 $(5 \mathrm{~g})$ and $2 \mathrm{ml} 0.1 \mathrm{M}$ phosphate buffer $(\mathrm{pH} 7.0)$. As Sephadex particles got settled inside the column, $100 \mu 1$ sample was injected to it. The sample was allowed to pass through the column and collected in collection tubes. The protein content of the collected fractions was determined by Bradford assay. The fractions showing more protein content were collected in one vessel. At this stage, the sample was ready for ion exchange chromatography.

Ion exchange chromatography: A column was filled with DEAE G-100. The sample collected in the above step was allowed to run in it. Similarly, the fractions of the sample showing high protein content were collected in one vessel. The Bradford assay was performed. The collected samples were lyophilized and stored at $-20^{\circ} \mathrm{C}$. It was considered as a purified lipase which was used for optimization, SDSPAGE and industrial applications. 


\section{Optimization of purified lipase}

For optimization, $100 \mu$ l purified lipase was used. The quantification of lipase was performed by the methods of Bussamaraet al. ${ }^{22}$ and Liaqat et al. ${ }^{19}$ at different conditions as follows. The activity of purified enzyme was checked over a wide range of temperature i.e. $25,37,45$, $50,60,70,80$ and $90^{\circ} \mathrm{C}$. Different $\mathrm{pH}(5,6,7,8,9)$ were selected to check the activity of a purified lipase. Moreover, the activity of lipase was checked with $0.1 \mathrm{mM} \mathrm{Na}, \mathrm{K}, \mathrm{NH}_{4}, \mathrm{Zn}, \mathrm{Cr}, \mathrm{Ca}, \mathrm{Fe}, \mathrm{Mg}$ and $\mathrm{Mn}$ ions. The $0.1 \mathrm{mM}$ of various carbon sources i.e. glucose, fructose, maltose, lactose and galactose were used as various carbon sources. Different oils (1\% olive, sunflower, canola and mustard) were used. The wastes of banana, corn, wheat, sugarcane and pea peels were used as $1 \%$ in medium. The $1 \%$ peptone, yeast extract, casein and tryptone were checked. Finally, $0.1 \mathrm{mM}$ sodium dodecyl sulfate (SDS) was used in addition to some commercially available detergents (Ariel ${ }^{\circledR}$, Bonus $^{\circledR}$, Bright ${ }^{\circledR}$ and Surf Excel $\left.{ }^{\circledR}\right)$.The additives (1\%) used were; tween 20, tween 80 and triton X-100.

\section{Application assay for lipase}

The potential application of the purified assay was performed as follows. ${ }^{9,19}$ One $\mathrm{ml}$ petrol was taken in a clean test tube and $1 \mathrm{ml}$ fresh supernatant was added and mixed thoroughly. It was allowed to settle down. The tube was observed for the formation of any layer. LB medium containing $1 \%$ kerosene oil and $1 \%$ petrol was prepared. It was incubated with the $1 \%$ bacterial isolate and incubated at $37^{\circ} \mathrm{C}$ for $48 \mathrm{~h}$ in shaking incubator. After $48 \mathrm{~h}$, the turbidity of the growth was observed. In order to perform detergent assay, three beakers were taken. The first beaker was filled with $50 \mathrm{ml}$ water, second with $50 \mathrm{ml}$ purified lipase and third with $50 \mathrm{ml}$ detergent of registered brand. Two clean pieces of white cloth were taken, one was marked with blue ink and ketchup was thrown on the other piece. Both pieces were allowed to dry at room temperature. They were cut in three equal parts and dipped in three beakers. They were placed in beakers for 1 hour followed by washing with tap water. After washing, they were air-dried and compared with each other. In Bio-surfactant assay on a clean glass slide, a drop of olive oil was placed. The sample $(10 \mu 1)$ was placed in the center of the oil droplet. The change in the shape of oil drop was observed up to one minute.

\section{Results and discussion}

\section{Isolation and purification of bacterial isolates}

Lipases are enzymes that are responsible for splitting triglycerides to diacylglycerides, monoglycerides and fatty acids. ${ }^{19}$ They hold special significance in various industries like food, cosmetics, pharmaceutical etc. ${ }^{4}$ A deep insight into their properties like growth conditions, inducers, inhibitors, interaction with metal ions, detergents, etc. should be taken into consideration. ${ }^{1}$ The microbial world known to produce lipase is diverse. For having practical application, always non-pathogenic strain is preferred. In this context, Bacillus stands out the list. ${ }^{19}$ In addition to its non-pathogenic nature; it is easy to culture as well. This study for the first time reports a novel strain Bacillus glycinifermentans-MK840989 as a lipase producer. For this study, mobil-oil contaminated soil samples were collected for the isolation of an efficient lipase producer. The most efficient lipase producer was Bacillus species which was observed to be B. glycinifermentans according to $16 \mathrm{~S}$ rRNA sequencing. B. glycinifermentans was first time isolated from fermented soybean; it got its name from there. ${ }^{25}$
B. glycinifermentans are Gram positive, endospore-forming, motile and facultative anaerobes. To date, only three literatures related to $B$. glycinifermentans are published. ${ }^{25-27}$ In this study, it was isolated from oil change service from a local petrol pump.

\section{Screening of lipase producing bacteria}

All six bacterial isolates (SM-1, SM2 (MK840989), SM-3, SM4, SM-5 and SM-6) were lipase producers. They showed following zones of lipolysis on olive oil hydrolysis agar plates: $0.021 \mathrm{~cm}$, $0.044 \mathrm{~cm}, 0.031 \mathrm{~cm}, 0.011 \mathrm{~cm}, 0.029 \mathrm{~cm}$ and $0.020 \mathrm{~cm}$ by $\mathrm{SM}-1, \mathrm{SM}-2$, SM-3, SM-4, SM-5 and SM-6, respectively. Among all these, SM-2 (MK840989) showed more lipolytic activity. The same isolate showed more lipase activity $(0.19 \mathrm{~cm})$ on peptone yeast agar plates as well as in chromogenic assay $(0.28 \mathrm{~cm})$.

\section{Lipase quantification and selection}

Bacterial strain MK840989 showed the maximum amount of lipase $(55.1 \mu \mathrm{mol} / \mathrm{ml})$. On the basis of results obtained from lipase screening methods as well as quantification, MK840989strain was chosen for further experiments as it was found to be a best lipase producer. It was identified as Bacillus according to the biochemical tests. The 16S rRNA sequencing showed it Bacillus glycinifermentans. Thestrain got registered in NCBI GenBank under accession number MK840989. It showed zone of lipolysis of $0.044 \mathrm{~cm}$ on olive hydrolysis agar, $0.19 \mathrm{~cm}$ on peptone yeast agar and $0.28 \mathrm{~cm}$ on chromogenic plate. Its lipase was quantified and found to be $55.1 \mu \mathrm{mol} / \mathrm{ml}$. Liaqat et al. ${ }^{19}$ reported $42.7 \mu \mathrm{M} / \mathrm{ml}$ lipase from $B$. stratosphericus-MK788130. In this study, the growth of $B$. glycinifermentans was observed optimum at $80^{\circ} \mathrm{C}, \mathrm{pH}$ 5 and $1 \%$ olive oil (Figure 1). Our results are in partial agreement with Liaqat et al. ${ }^{19}$ who reported the optimum growth of $B$. stratosphericus at $\mathrm{pH} 5$ but at $50^{\circ} \mathrm{C}$. But it was in contradiction with Kim et al. ${ }^{25}$ who reported the optimum temperature range of B. glycinifermentans as $15-55^{\circ} \mathrm{C}$. Our results are in contradiction with the studies of Shivaji et al. ${ }^{28}$ and Ismail et al. ${ }^{29}$ who reported its optimum growth conditions of lipase producing Bacillus species as $8-37^{\circ} \mathrm{C}, \mathrm{pH} 6-10$ and $34.8^{\circ} \mathrm{C}$, and $\mathrm{pH}$ 6.98, respectively. B. glycinifermentans-MK840989 cells were induced by olive oil (Figure 2) which agrees with Liaqat et al..$^{19}$ but contradicts with the findings of Iqbal and Rehman, ${ }^{9}$ who observed slow growth of $B$. subtilis I-4 cells in the presence of olive oil. Adentunji and Olaniran, ${ }^{30}$ reported induction of B. aryabhattai SE3PB lipase by using sunflower oil in the growth medium. The induction in the presence of oil gives a clue of its potential application in oil bioremediation. ${ }^{31}$

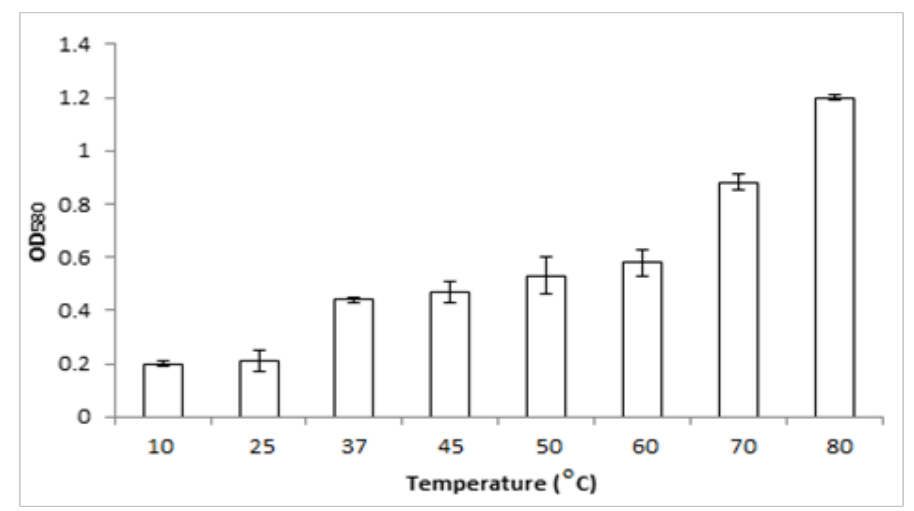



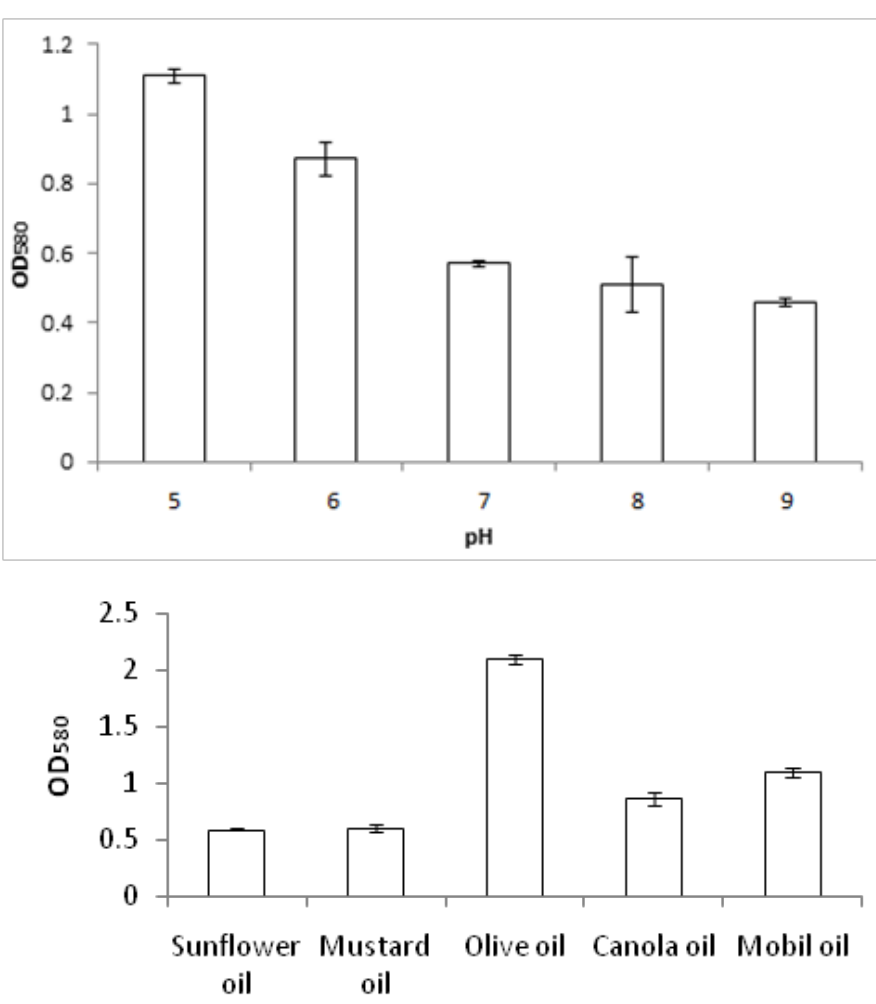

Carbon sources

Figure I The optimum growth of B. glycinifermentans MK-840989 was observed at $80^{\circ} \mathrm{C}, \mathrm{pH} 5$ and with $1 \%$ olive oil.

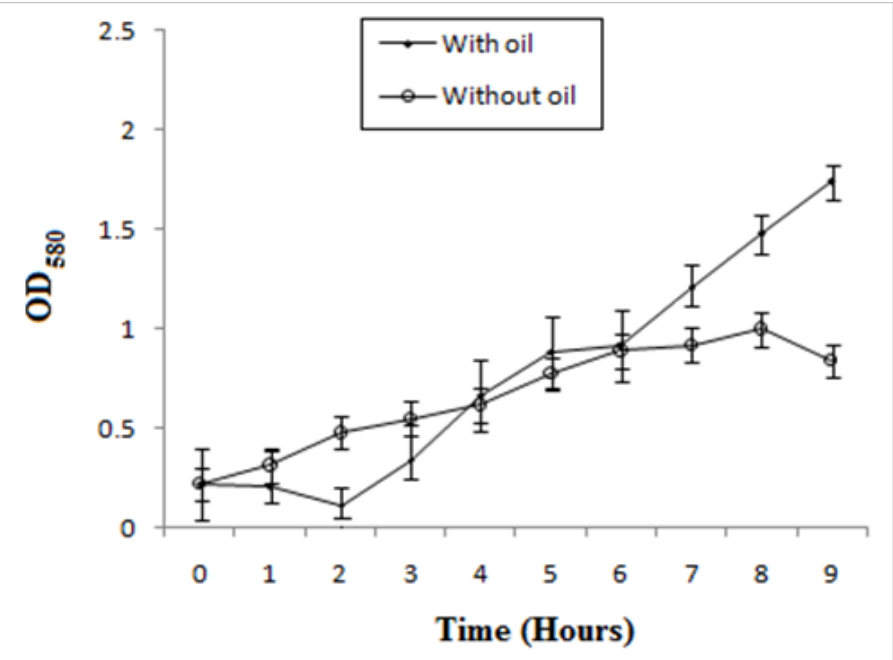

Figure 2 Growth curve study showed $1 \%$ olive oil as an inducer for $B$. glycinifermentans MK-840989 cells.

\section{Protein content of isolated and purified lipase}

According to Kornberg, ${ }^{32}$ the purification of enzyme from unnecessary impurities must be done as they hinder with its catalytic sites as well as its efficiency. The purification of bacterial lipases is previously reported by Andualema and Gessesse, ${ }^{33}$, Dey et al., ${ }^{34}$,
Rabbani et al., ${ }^{35}$, Bhosale et al., ${ }^{36}$, Sharma et al., ${ }^{37}$, Liaqat et al., ${ }^{19}$ In this study, the purification of B. glycinifermentans-MK840989 lipase resulted in decreased protein content from $350 \mathrm{mg} / \mathrm{ml}$ to $75 \mathrm{mg} / \mathrm{ml}$ (Table 1) which is in agreement with Borkar et al. ${ }^{38}$ who reported a similar decrease in protein concentration from $884 \mathrm{mg}$ to $0.68 \mathrm{mg}$ for $P$. aeruginosa SRT9 lipase during purification.

Table I Protein content $(\mathrm{mg} / \mathrm{ml})$ at different steps during lipase purification

\begin{tabular}{ll}
\hline Enzyme purification steps & Protein content $(\mathbf{m g} / \mathbf{m l})$ \\
\hline Supernatant (crude) & 350 \\
After ammonium sulphate precipitation & 211 \\
After dialysis & 98 \\
After column chromatography & 88 \\
After ion-exchange chromatography & 75 \\
\hline
\end{tabular}

\section{Optimization of lipase activity}

In this study,the purified lipase of B. glycinifermentans-MK840989 showed optimum activity at $90^{\circ} \mathrm{C}, \mathrm{pH} 5$ and $\mathrm{Ca}^{+}$(Figures $3 \mathrm{a}-3 \mathrm{c}$ ), $0.1 \mathrm{mM}$ maltose, $1 \%$ olive oil, $1 \%$ yeast extract (Figures $4 \mathrm{a}-\mathrm{c}$ ), $1 \%$ wheat waste, commercial detergent and tween-20 (Figures 5a-5c). Our results are in agreement with Liaqat et al. ${ }^{19}$ who reported the same optimum conditions $\left(90^{\circ} \mathrm{C}\right.$ and $\left.\mathrm{pH} 5\right)$ for lipase activity of $B$. stratosphericus-MK 788130. According to Xiao et al., ${ }^{39}$ lipase usually performs lipolysis between $\mathrm{pH} \mathrm{4-11} \mathrm{and} \mathrm{its} \mathrm{optimum} \mathrm{temperature}$ ranges between $30-60^{\circ} \mathrm{C}$. According to Lomthaisong et al., ${ }^{40}$ the lipase of $P$. xinjiangensis CFS14 showed maximum activity at $37^{\circ} \mathrm{C}, \mathrm{pH} 8$ and in the presence of $\mathrm{Mg}^{2+}$ ions. Bacillus sp. W13035 lipase, isolated from tidal mud flat showed its maximal activity at $\mathrm{pH} 9,60^{\circ} \mathrm{C}$ and $\mathrm{Ca}^{2+}$ ions. ${ }^{7,25}$ Tambekar et al. ${ }^{41}$ reported alkaline lipase production at $\mathrm{pH} 9$ and $60^{\circ} \mathrm{C}$ by B. flexus. In another study, ${ }^{42}$ the lipase of $B$. flexus was found functioning optimally at $\mathrm{pH} 10$ and $70^{\circ} \mathrm{C}$. It was furthermore studied by the same group that this lipase was stable in tween-80 and triton X-100 which partially agrees with our findings (Figure $5 \mathrm{c}$ ) as here maximum lipase activity was observed with tween-20 and minimum with triton X-100. B. flexus lipase also showed stability in the presence of commercially available detergents which strongly agree with our investigations. ${ }^{42}$ For $B$. subtilis $\mathrm{I}-4$, the optimum enzyme activity conditions were; $50^{\circ} \mathrm{C}, \mathrm{pH}$ 7.0, Ca ions, olive oil and tween 80. ${ }^{9}$ Habibollahi and Salehzadeh, ${ }^{10}$ presented their investigations about lipase of Pseudomonas sp. KY 288051 as follows: $37^{\circ} \mathrm{C}, \mathrm{pH} 7$, peptone and olive oil. The lipase of Staphylococcus aureus worked optimum $(15.8 \mathrm{U} / \mathrm{ml})$ at $37^{\circ} \mathrm{C}$ and $\mathrm{pH}$ 7 and peptone. ${ }^{43}$ In their study, olive oil induced the expression of lipase $(12.5 \mathrm{U} / \mathrm{ml})$ which is in agreement with our results. Previous literatures also supported our results. ${ }^{44,45}$ The lipase obtained from B. cereus showed maximum activity at $\mathrm{pH} 8(60.2 \mathrm{U} / \mathrm{ml}), 35^{\circ} \mathrm{C}$ $(55.25 \mathrm{U} / \mathrm{ml})$, maltose $(66 \mathrm{U} / \mathrm{ml})$ and peptone $(66 \mathrm{U} / \mathrm{ml}) .{ }^{6}$ The lipase of $B$. sonorensis $4 \mathrm{R}$ had highest activity at $80^{\circ} \mathrm{C}, \mathrm{pH} 9, \mathrm{Mg}$ and $\mathrm{Ca}$ ions. ${ }^{36}$ The lipase of a psychrophilic strain of Pseudomonas sp. LSK25 was obtained at $10^{\circ} \mathrm{C}$ and $\mathrm{pH} 7 .^{6}$ The purified enzymes isolated from Pseudomonas reinekei were found to be stable over a wide range of $\mathrm{pH} 5-9$ and at $40^{\circ} \mathrm{C} .{ }^{47,48}$ According to Zarinviarsagh et al., ${ }^{49}$ the yield of Ochrobactrum intermedium MZV101 lipase was $69 \%$ which was found stable at $\mathrm{pH} 10-13$ and $70-90^{\circ} \mathrm{C}$. The fructose was found to be the best carbon source for optimal functioning of lipase $(0.1 \mathrm{U} / \mathrm{ml})$ which contradicts with the findings of Sooch and Kauldhar, ${ }^{50}$ wherein it induced $53.2 \mathrm{IU} / \mathrm{ml}$ lipase activity as compared to that by glucose 
(77.2IU/ml). In another study, $1.5 \%$ glucose was reported as the best carbon source for lipase activity $(1590 \mathrm{U} / \mathrm{mg}$ ) followed by $1-2 \%$ fructose (1595U/mg) for Bacillus sp. ZR-5. ${ }^{51}$ According to Mazhar et al. ${ }^{52}$ maltose made a maximum lipase expression $(28.91 \mathrm{U} / \mathrm{ml})$ of $B$. cereus PCSIR NL-37 followed by fructose $(27.2 \mathrm{U} / \mathrm{ml}) .^{53}$

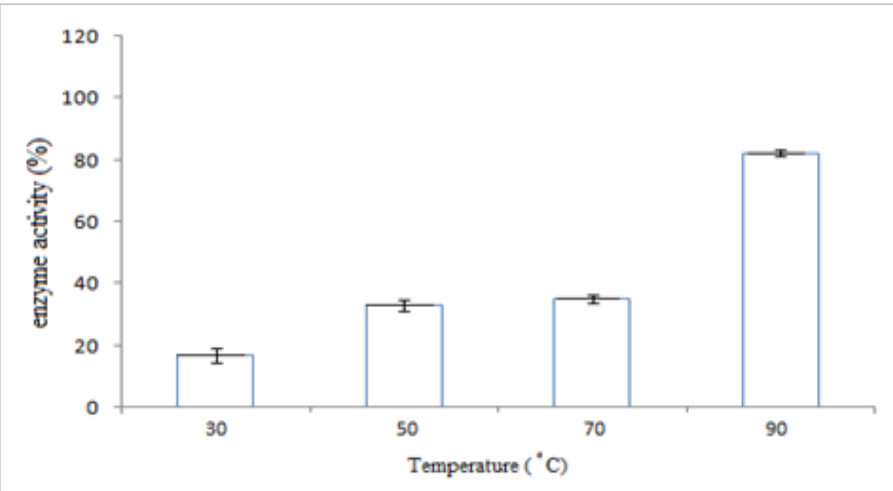

(a)

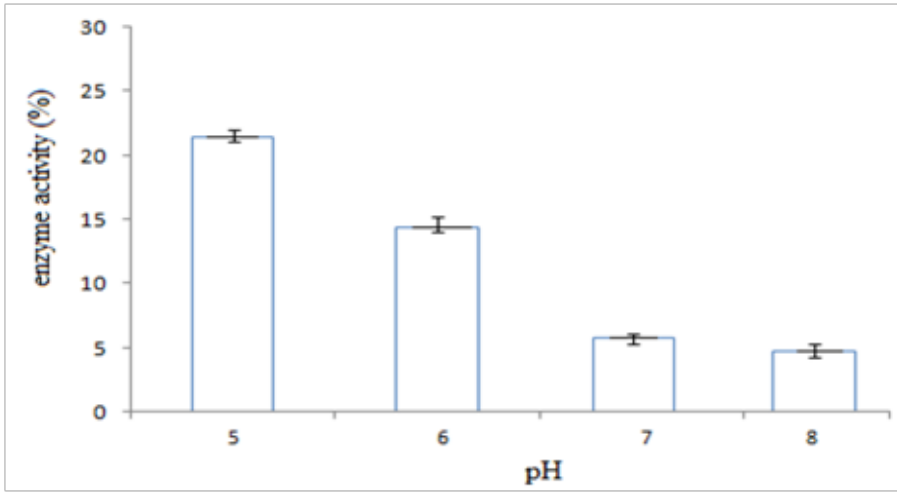

(b)

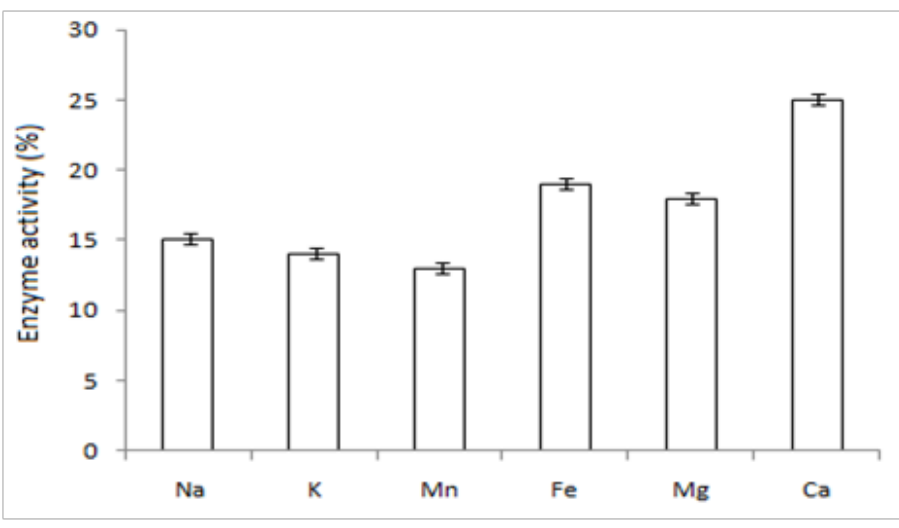

(c)

Figure 3 Graph showing optimum enzyme activity at different (a) temperatures $\left(90^{\circ} \mathrm{C}\right),(\mathrm{b}) \mathrm{pHs}(\mathrm{pH} 5)$, and $(\mathrm{c})$ metal ions $\left(\mathrm{Ca}^{+}\right)$.

\section{Potential industrial application}

As the purified lipase of B.glycinifermentans-MK840989 was found to be thermostable and acidic, it showed a potential application as a detergent. The lipase of $B$. glycinifermentans-MK840989 showed potential application as a detergent. Our results are in contradiction with Liaqat et al. ${ }^{19}$ and Iqbal and Rehman, ${ }^{9}$ who reported the potential application of purified lipase of B. stratosphericus-MK788130 and B. cereus I-4 as a biosurfactant. Detergents are compounds that remove fatty acids and dirt particles. ${ }^{54}$ They are used in laundry for cleaning fabrics. They impart softness, anti-staticness and resiliency to fabrics. However, synthetic detergents persist for unlimited time period which contaminates the water bodies thus harmful for the environment. The green detergent or bio-detergents from microorganisms are the need of this hour. ${ }^{55}$ The previous literature already reported the property of microbial lipase as a detergent ${ }^{14,42}$ in Staphylococcus,${ }^{56,57}$ Acinetobacter, ${ }^{58-61}$ Bacillus,,${ }^{15,20,62-64}$ Pseudomonas, ${ }^{65-67}$ Streptomyces ${ }^{68,69}$ and Burkholderia. ${ }^{59}$

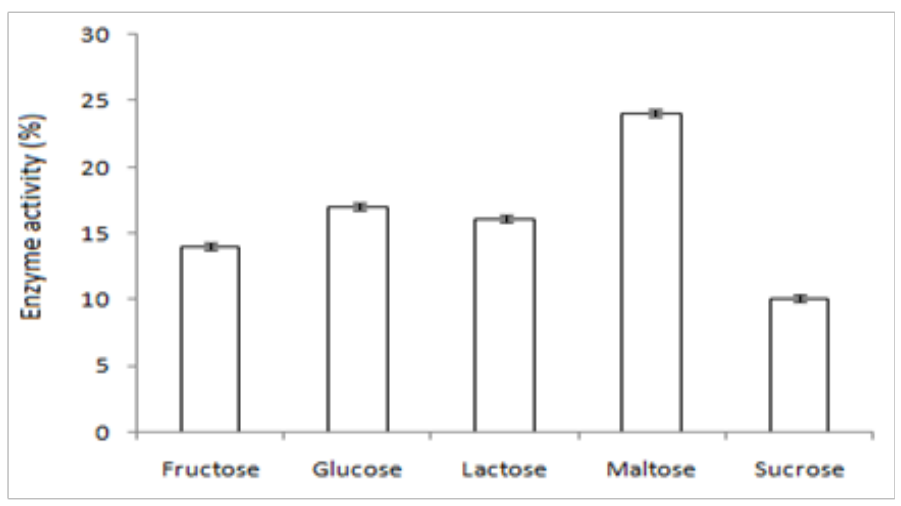

(a)

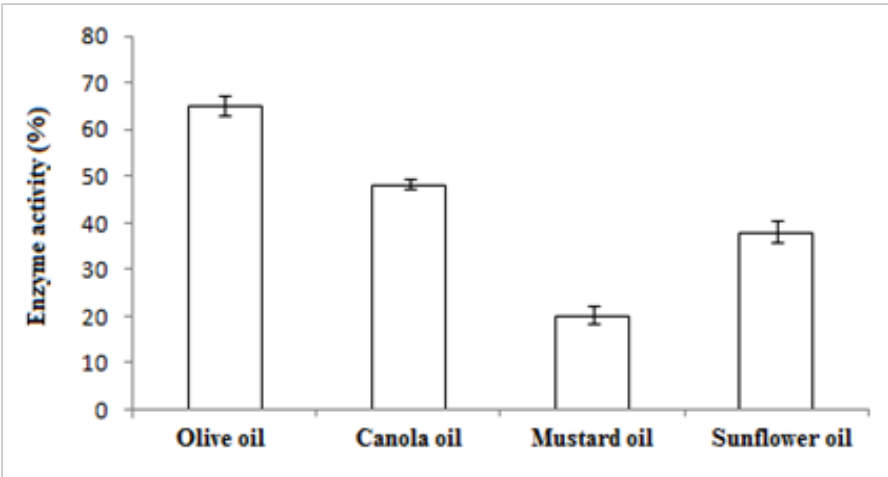

(b)

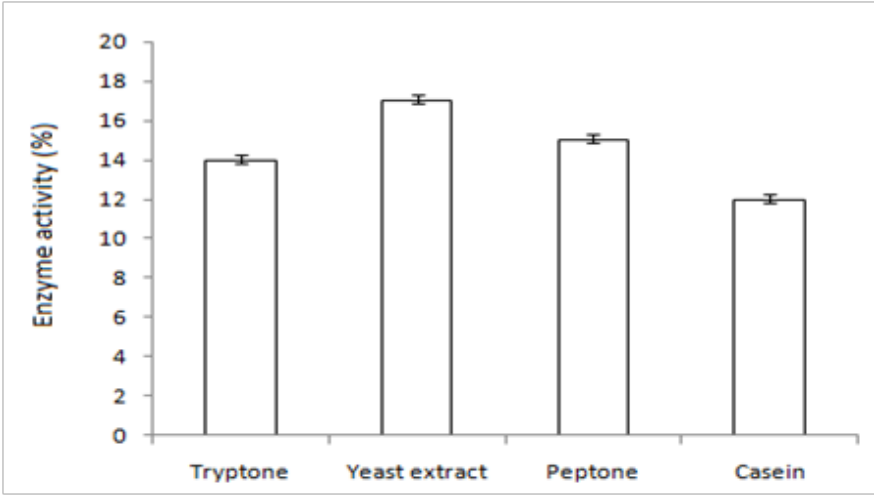

(c)

Figure 4 Graph showing optimum enzyme activity at (a) carbon sources (maltose), (b) oils ( $1 \%$ olive oil), and (c) nitrogen sources (yeast extract). 


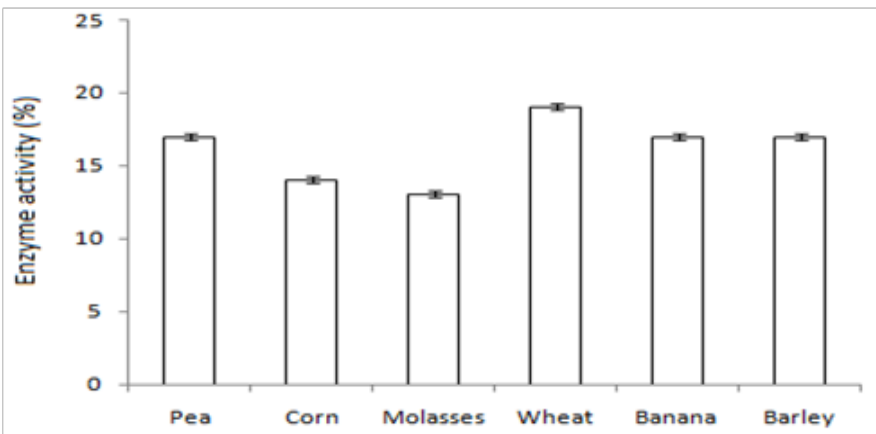

(a)

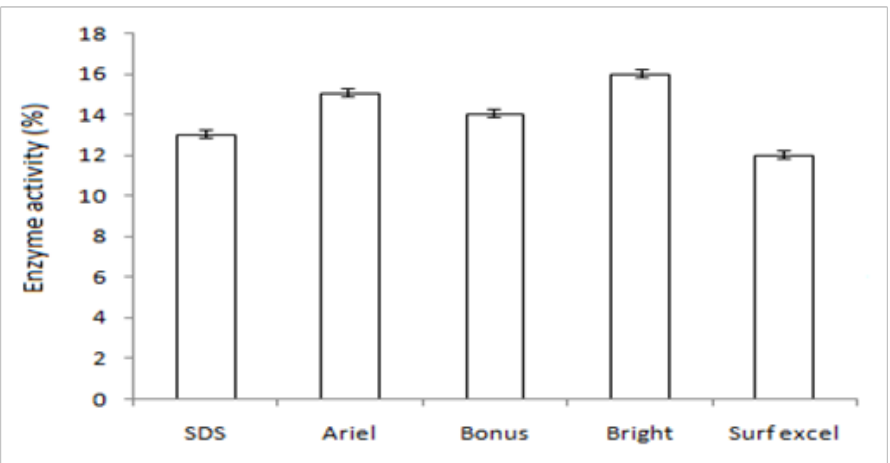

(b)

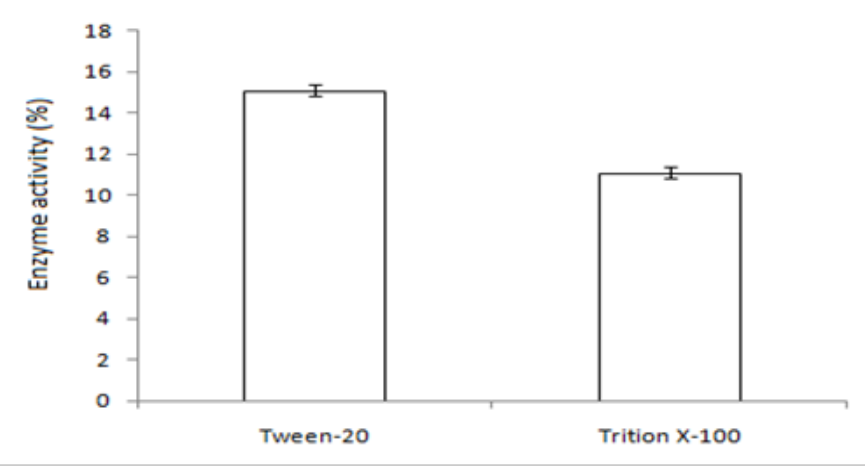

(c)

Figure 5 Graph showing optimum enzyme activity at (a) wastes (wheat), (b) detergents $\left(\right.$ Bright $\left.^{\circledR}\right)$ and (c) additives (Tween-20).

\section{Molecular weight of lipase}

Here polypeptide of the purified lipase of B. glycinifermentansMK840989 was of $26.7 \mathrm{kDa}$ (Figure 6). Liaqat et al. ${ }^{19}$ reported $14 \mathrm{kDa}$ lipase from $B$. stratosphericus-MK788130. The lipase of $O$. intermedium MZV101 was of $99.42 \mathrm{kDa}$ as studied by Zarinviarsagh et al. ${ }^{49}$ Rabbani et al. ${ }^{35}$ reported $31 \mathrm{kDa}$ lipase from $B$. subtilis. Gururaj et al. ${ }^{70}$ observed lipase of $45 \mathrm{kDa}$ in Acinetobacter sp. AU07. Similarly previous literatures shows lipase of different molecular weights as $13.9 \mathrm{kDa}, 31.3 \mathrm{kDa}, 43 \mathrm{kDa}$ and $50 \mathrm{kDa}$ in psychrotrophic Pseudomonas ADT3, ${ }^{34}$ Enterobacter sp. Bn12, ${ }^{71}$ Staphylococcus SDMlip, ${ }^{72}$ Leuconostocmesenteroides subsp. mesenteroides ATCC $8293^{73}$ and Pseudomonas reinekei, ${ }^{47}$ respectively.

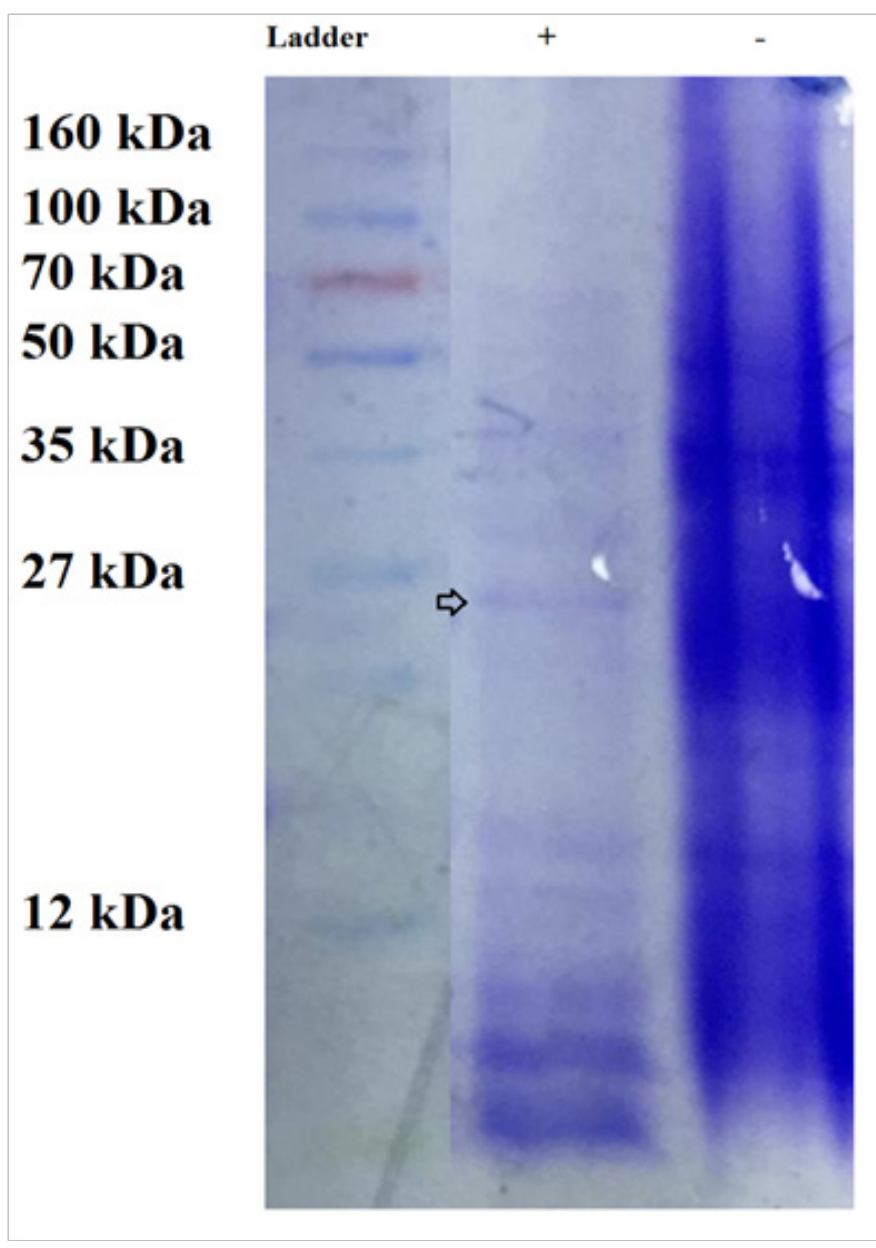

Figure 6 The SDS-PAGE showing the expression of lipase of 26.7kDa in the presence of I\% olive oil. The band of lipase is shown as encircled band in the figure.

\section{Discussion}

This study for the first time reported the isolation, purification and optimization of lipase from B. glycinifermentans MK-840989. It was found to be thermostable acidic bacterium which was induced by olive oil for the production of lipase. It possessed thermostable acidic lipase which enlightens its potential application in detergent and oilbioremediation industries.

\section{Acknowledgments}

This study was not funded by any agency or organization.

\section{Funding}

None.

\section{Conflicts of interest}

The authors declare no conflict of interest. 


\section{References}

1. Shamim S, Liaqat U, Rehman A. Microbial lipases and their applications - a review. Abasyn J Life Sci. 2018;1(2):54-76.

2. Guerrand D. Lipases industrial applications: focus on food and agroindustries. Lipids Future. 2017;24(4):1-7.

3. Javed S, Azeem F, Hussain S, et al. Bacterial lipases: a review on purification and characterization. Prog Biophys Mol Biol. 2018;13:2334.

4. Daroonpunt R, Tanaka N, Uchino M, et al. Characterization and screening of lipolytic bacteria from Thai fermented fish. Sains Malaysiana. 2018;47(1):91-97.

5. Zheng C. Screening and identification of lipase producing bacterium. IOP Conference Series: Earth Environ Sci. 2017;108:1-8.

6. Ghaima KK, Mohamed AI, Mohamed MM. Effect of some factors on lipase production by Bacillus cereus isolated from diesel fuel polluted soil. Int J Sci Res Publ. 2014;4(8):1-5.

7. Kim HJ, Jung WK, Lee HW, et al. Characterization of an alkaline family 1.4 lipase from Bacillus sp. W130-35 isolated from a tidal mud flat with broad substrate specificity. J Microbiol Biotechnol. 2015;25(12):2024-2033.

8. Sangeetha R, Arulpandi I, Geetha A. Molecular characterization of a proteolysis-resistant lipase from Bacillus pumilus SG2. Brazil J Microbiol. 2014;45(2):389-393.

9. Iqbal SA, Rehman A. Characterization of lipase from Bacillus subtilis I-4 and its potential used in oil contaminated wastewater. Brazil Arch Bio Technol. 2015;58(5):789-797.

10. Habibollahi H, Salehzadeh A. Isolation, optimization, molecular characterization of a lipase producing bacterium from oil contaminated soils. Pollution. 2017;4(1):119-128.

11. Shabbir AR, Mukhtar H. Optimization process for enhanced extracellular lipases production from a new isolate of Aspergillus terreusAH-F2. Pak J Bot. 2018;50(4):1571-1578.

12. Ali I, Jamil N. Biosynthesis and genetics of polyhydroxyalkanoates by newly isolated Pseudomonas aeruginosa IFS and 30N using inexpensive carbon sources. Int J Environ Sci Technol. 2017;14(9):1879-1888.

13. Pliego J, Mateos JC, Rodriguez J, et al. Monitoring lipase/esterase activity by stopped flow in a sequential injection analysis system using p-nitrophenyl butyrate. Sensors. 2015;15:2798-2811.

14. Niyonzima FN, More S. Biochemical properties of the alkaline lipase of Bacillus flexus XJU-1 and its detergent compatibility. Biologia. 2014;69(9):1108-1117.

15. Lailaja VP, Chandrasekaran M. Detergent compatible alkaline lipase produced by marine Bacillus smithii BTMS11. World J Microbiol Biotechnol. 2013;29:1349-1360.

16. Hasan F, Shah AA, Hameed A. Industrial applications of microbial lipases. Enzyme Microb Technol. 2006;39:235-251.

17. Annamalai N, Elayaraja S, Vijayalakshmi S, et al. Thermostable, alkaline tolerant lipase from Bacillus licheniformis using peanut oil cake as a substrate. Afr J Biochem Res. 2011;5:176-181.

18. Cheesbrough M. Biochemical tests to identify bacteria. District laboratory practice in tropical countries - part 2. Cambridge University Press; 2001:63-70

19. Liaqat M, Shamim S, Malik A, et al. Process optimization for obtaining maximum yield of alkaline thermostable lipase from Bacillus stratosphericus-MK788130. J Basic Microbiol. 2019.
20. Amara AA, Salem SS, Shabeb MSA. The possibility to use bacterial protease and lipase as a detergent. Global J Biotechnol Biochem. 2009;4:104-114.

21. Bussamara R, Fuentefria AM, Oliveira ES, et al. Isolation of a lipasesecreting yeast for enzyme production in a pilot-plant scale batch fermentation. Bioresour Technol. 2010;101:268-275.

22. Winkler UK, Stuckmann M. Glycogen, hyaluronate, and some other polysaccharides greatly enhance the formation of exolipase by Serratia marcescens. J Bacteriol. 1979;138(3):663-670.

23. Cold spring harbor protocols. 2016.

24. Bradford MM. A rapid and sensitive method for the quantitation of microgram quantities of protein utilizing the principle of protein-dye binding. Anal Biochem. 1970;72:248-254.

25. Kim S-J, Dunlap CA, Kwon S-W, et al. Bacillus glycinifermentans sp. nov., isolated from fermented soybean paste. Int J SysEvol Microbiol. 2015;65:3586-3590.

26. Zeigler DR. Genome sequence of Bacillus glycinifermentans TH008, isolated from Ohio soil. Genome Announce. 2016;4(1):1.

27. Stadermann KB, Blom J, Borgmeier C, et al. First complete genome sequence of Bacillus glycinifermentans B-27. J Biotech. 2017;257:187191.

28. Shivaji S, Chaturvedi P, Suresh K, et al. Bacillus aerius sp. nov., Bacillus aerophilus sp. nov., Bacillus stratosphericus sp. nov. and Bacillus altitudinis sp. nov., isolated from cryogenic tubes used for collecting air samples from high altitudes. Int J Sys Evol Microbiol. 2006;56:1465-1473.

29. Ismail AR, El-Henawy SB, Younis SA, et al. Statistical enhancement of lipase extracellular production by Bacillus stratosphericus PSP8 in a batch submerged fermentation process. $J$ Appl Microbiol. 2018;125(4):1076-1093.

30. Adetunji AI, Olaniran AO. Optimization of culture conditions for enhanced lipase production by an indigenous Bacillus aryabhattai SE3-PB using response surface methodology. Biotechnol Biotechnol Equip. 2018;32(6):1514-1526.

31. Lee LP, Karbul HM, Citartan M, et al. Lipase-screening Bacillus species in an oil-contaminated habitat: promising strains to alleviate oil pollution. BioMed Res Int. 2015:1-9.

32. Kornberg A. Chapter 1 Why purify enzymes? Methods in Enzymology. 2009;463:3-6.

33. Andualema B, Gessesse A. Microbial lipases and their industrial applications: review. Biotechnology. 2012;11(3):100-118.

34. Dey A, Chattopadhyay A, Mukhopadhyay SK, et al. Production, partial purification and characterization of an extracellular psychrotrophic lipase from Pseudomonas sp. ADT3. $J$ Bioremed Biodegrad. 2014;5(6):242-249.

35. Rabbani MJ, Shafiee F, Shayegy Z, et al. Isolation and characterization of a new thermophilic lipase from soil bacteria. Iran J Pharma Res. 2015;14(3):901-906.

36. Bhosale H, Shaheen U, Kadam T. Characterization of a hyperthermostable alkaline lipase from Bacillus sonorensis 4R. Enzyme Res. 2016:1-11.

37. Sharma P, Sharma N, Pathania S, et al. Purification and characterization of lipase by Bacillus methylotrophicus PS3 under submerged fermentation and its application in detergent industry. $J$ Genetic Eng Biotech. 2017;15(2):369-377.

38. Borkar PS, Bodade RG, Rao SR, et al. Purification and characterization 
of extracellular lipase from a new strain - Pseudomonas aeruginosa SRT9. Brazil J Microbiol. 2009;40:358-366.

39. Xiao F, Li Z, Pan L. Application of microbial lipase and its research progress. Prog Appl Microbiol. 2017:8-14.

40. Lomthaisong K, Buranarom A, Niamsup H. Investigation of isolated lipase producing bacteria from oil-contamianed soil with proteomic analysis of its proteins responsive to lipase inducer. $J$ Biol Sci. 2012;12(3):161-167.

41. Tambekar DH, Tambekar SD, Jadhav AS, et al. Alkaliphilic Bacillus flexus: a potential source of lipase producer for industrial and medical applications. IntJ Pharma Sci Res. 2017;8(10):4313-4317.

42. Niyonzima FN, More SS. Concomitant production of detergen compatible enzymes by Bacillus flexus XJU-1. Brazil J Microbiol. 2014;45(3):903-910

43. Sirisha E, Rajasekar N, Narasu ML. Isolation and optimization of lipase producing bacteria from oil contaminated soils. Adv Biol Res. 2010;4(5):249-252.

44. Muralidhar RV, Marchant R, Nigam P. Lipase in racemic resolutions. Chem Technol Biotechnol. 2001;76(1):3-8

45. Fadiloglu S, Erkmen O. Effects of carbon and nitrogen sources on lipase production by Candida rugosa. Turk J Eng Environ Sci. 2002;26(10):249-254

46. Salwoom L, Rahman RNZRA, Salleh AB, et al. Isolation, characterization, and lipase production of a cold-adapted bacteria strain Pseudomonas sp. LSK25 isolated from Signy Island, Antarctica. Molecules. 2019;24(4):715-729.

47. Priyanka P, Kinsella G, Henehan GT, et al. Isolation, purification and characterization of a novel solvent stable lipase from Pseudomonas reinekei. Protein Express Purif. 2019;153:121-130.

48. Ryan B, Priyanka P, Tan Y, et al. Isolation, purification and characterization of a novel solvent stable lipase from Pseudomonas reinekei. Protein Express Purif. 2019;153:121-130.

49. Zarinviarsagh M, Ebrahimipour G, Sadeghi H. Lipase and biosurfactan from Ochrobactrum intermedium strain MZV101 isolated by washing powder for detergent application. Lipids Hlth Dis. 2017;16:177-189.

50. Sooch BS, Kauldhar BS. Influence of multiple bioprocess parameters on production of lipase from Pseudomonas sp. BWS-5. Brazil Arch Biol Tech. 2013;56(5):711-721.

51. Soleymani S, Alizadeh H, Mohammadian H, et al. Efficient media for high lipase production: one variable at a time approach. Avicenna $J$ Med Biotech. 2017;9(2):82-86.

52. Mazhar H, Abbas N, Hussain Z, et al. Extracellular lipase production from Bacillus subtilis using agro-industrial waste and fruit peels. Punjab Uni J Zool. 2016;31(2):261-267.

53. Mazhar H, Abbad N, Zamir T, et al. Optimization study of lipolytic enzyme from Bacillus cereus, PCSRI NL-37. Punjab Uni J Zool. 2018;33(2):217-224

54. Vulfson EN. Industrial applications of lipases. In: Wooley P, Petersen SB, editors. Cambridge, Great Britain: Cambridge University Press; 1994. $271 \mathrm{p}$.

55. Hasan F, Shah AA, Javed S, et al. Enzymes used in detergents: lipases - review. Afr J Biotechnol. 2010;9(31):4836-4844.

56. Cherif S, Mnif S, Hadrich F, et al. A newly high alkaline lipase: an indeal choice for application in detergent formulations. Lipids Hlth Dis. 2011;10:221-228
57. Chauhan M, Chauhan RS, Garlapati VK. Evaluation of a new lipase from Staphylococcus sp. detergent additive capability. BioMed Res Int 2013:1-6.

58. Saisubramanian N, Sivasubramanian S, Nandakumar N, et al. Two step purification of Acinetobacter sp. lipase and its evaluation as a detergent additive at low temperatures. Appl Biochem Biotechnol. 2008; 150:139-156

59. Wang H, Liu R, Lu F, et al. A novel alkaline and low-temperature lipase of Burkholderiacepacia isolated from Bohai in China for detergent formulation. Ann Microbiol. 2009;59:105-110.

60. Khoramnia A, Ebrahimpour A, Beh BK, et al. Production of a solvent, detergent, and thermotolerant lipase by a newly isolated Acinetobacter sp. in submerged and solid-state fermentations. J Biomed Biotechnol. 2011:1-12

61. Wang $\mathrm{H}$, Zhong $\mathrm{S}$, Ma $\mathrm{H}$, et al. Screening and characterization of a novel alkaline lipase from Acinetobacter calcoaceticus 1-7 isolated from Bohai bay in China for detergent formulation. Brazil J Microbiol. 2012;43:148-156.

62. Bayoumi RA, El-louboudey SS, Sidkey NM, et al. Production, purification and characterization of thermo-alkalophilic lipase for application in bio-detergent industry. J Appl Sci Res. 2007;3:17521765.

63. Nerurkar M, Manasi J, Sujata P, et al. Application of lipase from marine bacteria Bacillus sonorensis as an additive in detergent formulation. $J$ SurfactDeterg. 2013;16:435-443.

64. Niyonzima FN, More SS. Screening and identification of a novel alkaline lipase producing bacterium. Int JPharma Bio Sci. 2013;4(2):1037-1045.

65. Khoo ML, Ibrahim CO. Lipase from thermoalkalophilic Pseudomonas species as an additive in potential laundry detergent formulations. Malaysian J Microbiol. 2009;5:1-5.

66. Kanimozhi S, Perinbam K. Application of an alkaline lipase from Pseudomonassp. Lp1 as bio-detergent. Adv Biotech. 2011;10:28-31.

67. Mobarak-Qamsari E, Kasra-Kermanshahi R, Moosavinejad Z Isolation and identification of a novel, lipase-producing bacterium, Pseudomonas aeruginosa KM110. Iran J Microbiol. 2011;3:92-98.

68. Gunalakshmi B, Sahu M, Sivakumar K, et al. Investigation on lipase producing actinomycete strain LE-1 isolate from a shrimp pond. Res $J$ Microbiol. 2008;3:73-81.

69. Aly MM, Tork S, Al-Garni SM, et al. Production of lipase from genetically improved Streptomyces exfoliates LP10 isolated from oilcontaminated soil. Afr J Microbiol Res. 2012;6:1125-1137.

70. Gururaj P, Ramalingam S, Devi GN, et al. Process optimization for production and purification of a thermostable, organic solvent tolerant lipase from Acinetobacter sp. AU07. Brazil J Microbiol. 2016;47(3):647-657

71. Farrokh P, Yakhchali B, Karkhane AA. Cloning and characterization of newly isolated lipase from Enterobacter sp. Bn12. Brazil J Microbiol. 2014;45(2):677-687.

72. Tipre DR, Purohit MS, Dave SR. Production and characterization of lipase from Staphylococcus sp. SDMlip. Int J Curr Microbiol Appl Sci. 2014;3(6):423-436.

73. Sukohidayat NHE, Zarei M, Baharin BS, et al. Purification and characterization of lipase produced by Lecuonostocmesenteroides subsp. mesenteroides ATCC 8293 using an aqueous two-phase system (ATPS) composed of triton X-100 and maltitol. Molecules. 2018;23:117. 